\title{
Cangrelor ameliorates CLP-induced pulmonary injury in sepsis by inhibiting GPR17
}

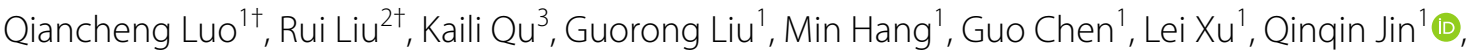 \\ Dongfeng Guo ${ }^{1 *}$ and Qi Kang ${ }^{1 *}$
}

\begin{abstract}
Background: Sepsis is a common complication of severe wound injury and infection, with a very high mortality rate. The P2Y12 receptor inhibitor, cangrelor, is an antagonist anti-platelet drug.

Methods: In our study, we investigated the protective mechanisms of cangrelor in CLP-induced pulmonary injury in sepsis, using C57BL/6 mouse models.

Results: TdT-mediated dUTP Nick-End Labeling (TUNEL) and Masson staining showed that apoptosis and fibrosis in lungs were alleviated by cangrelor treatment. Cangrelor significantly promoted surface expression of CD40L on platelets and inhibited CLP-induced neutrophils in Bronchoalveolar lavage fluid (BALF) $(p<0.001)$. We also found that cangrelor decreased the inflammatory response in the CLP mouse model and inhibited the expression of inflammatory cytokines, IL-1 $\beta(p<0.01)$, IL-6 $(p<0.05)$, and TNF- $a(p<0.001)$. Western blotting and RT-PCR showed that cangrelor inhibited the increased levels of G-protein-coupled receptor 17 (GPR17) induced by CLP $(p<0.001)$.
\end{abstract}

Conclusion: Our study indicated that cangrelor repressed the levels of GPR17, followed by a decrease in the inflammatory response and a rise of neutrophils in BALF, potentially reversing CLP-mediated pulmonary injury during sepsis.

Keywords: Sepsis, Inflammation, Cangrelor, Platelet, GPR17

\section{Background}

Sepsis is a serious disease and will lead a high mortality rate of approximately $22 \%$ in all over the world [1]. It has several features like out of controlled inflammatory response, coagulation disorder, and immune dysfunctions [2]. The cause of sepsis is complex, and its main cause is a response caused by the host's immune response to the pathogen $[2,3]$. Overall, the physiological and pathological mechanisms of sepsis are well researched. A lot of mediators such as cytokines, chemokines, and free radicals participate in the development of sepsis [4].

\footnotetext{
*Correspondence: gdf3789@163.com; 2601072234@qq.com

${ }^{\dagger}$ Qiancheng Luo and Rui Liu contributed equally to this work.

${ }^{1}$ Department of Critical Care Medicine, Shanghai Gongli Hospital, The

Second Military Medical University, Shanghai 200135, People's Republic of China

Full list of author information is available at the end of the article
}

The lung is one of the initial target organ of the systemic inflammatory response caused by sepsis, leading to alveolar or capillary epithelial cell injury, diffuse pulmonary interstitial edema, and inflammatory cell exudation (i.e., acute lung injury/respiratory distress syndrome, progressive respiratory distress, and hypoxemia) and then acute respiratory failure and non-cardiogenic pulmonary edema [5-8]. Despite numerous treatment strategies, drugs that effectively improve the treatment of sepsis remain to be developed. Antibiotics are the key method for clinical treatment, but the death rate of sepsis still reaches an astonishing number of 30-40\% [9].

In the past few years, the treatment of sepsis-related coagulopathy has been widely investigated. Recent studies have found that there is a coagulation-inflammation cross-reaction system with platelet-leukocyte aggregates as the core pathogenesis of sepsis [10]. With inhibition of platelet activation by anti-platelet drugs being used

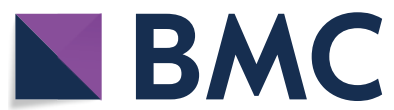

(c) The Author(s) 2021. This article is licensed under a Creative Commons Attribution 4.0 International License, which permits use, sharing, adaptation, distribution and reproduction in any medium or format, as long as you give appropriate credit to the original author(s) and the source, provide a link to the Creative Commons licence, and indicate if changes were made. The images or other third party material in this article are included in the article's Creative Commons licence, unless indicated otherwise in a credit line to the material. If material is not included in the article's Creative Commons licence and your intended use is not permitted by statutory regulation or exceeds the permitted use, you will need to obtain permission directly from the copyright holder. To view a copy of this licence, visit http://creativeco mmons.org/licenses/by/4.0/. The Creative Commons Public Domain Dedication waiver (http://creativecommons.org/publicdomain/ zero/1.0/) applies to the data made available in this article, unless otherwise stated in a credit line to the data. 
to treat sepsis/acute lung injury, the high risk of patients could be reduced organ damage and alleviated conditions $[11,12]$. Former studies have found that P2Y12 receptor antagonists such as clopidogrel and ticagrelor treat sepsis and lung damage through anti-platelet aggregation effects [13-15]. The P2Y12 receptor belongs to a proteincoupled receptor and is one of two receptors on platelets. The P2Y12 receptor is also the initiation channel for platelet activation, and the receptor strongly amplifies signal activation. This amplification is displayed not only in the magnification of the platelet aggregation signal, as well as in subsequent multi-step signaling, including the release of platelet particles and the enhancement of platelet-promoting activity $[16,17]$. P2Y12 receptor antagonists prevent the formation of neutrophil-platelet aggregates by inhibiting the recruitment of neutrophils, significantly reducing thrombocytopenia, and also reducing lung damage caused by sepsis [18-20]. However, the therapeutic mechanism of cangrelor on sepsis has not been reported. Our research aims were to characterize the potential effect of cangrelor on sepsis and to identify its mechanism of action.

\section{Materials and methods Drugs and reagents}

Cangrelor (98\% pure) was obtained from Vcare PharmaTech Co., Ltd (Shanghai, China). Myeloperoxidase (MPO) kit was obtained from Nanjing Jiancheng (Jiangsu, China). BCA Protein Assay was obtained from Thermo Fisher (MA, USA). Anti-CD40L (\#15094, 1:1000) and $\beta$-actin (\#4970, 1:1000) were obtained from Cell Signalling Technology (MA, USA). Anti-GPR17 (ab75553, 1:500) was obtained from Abcam (Shanghai, China). Enzyme-linked immunosorbent assay (ELISA) kits were obtained from RapidBio (CA, USA). TRIzol reagent was obtained from Life Technology (CA, USA). PrimeScript ${ }^{\circledR}$ RT Master Mix and SYBR ${ }^{\circledR}$ Premix Ex Taq ${ }^{\mathrm{TM}}$ were purchased from Takara (Dalian, China). All other reagents were obtained from Sigma-Aldrich (Shanghai, China).

\section{Animal treatment}

C57BL/6 mice $(20 \pm 2 \mathrm{~g})$ were purchased from Shanghai Laboratory Animal Center (Shanghai, China) and fed according to guidelines approved by the Experimental Animal Ethical Committee of Pudong New Area Gongli Hospital. They were raised in a constant temperature and humidity room $\left(22 \pm 1{ }^{\circ} \mathrm{C}, 65 \pm 5 \%\right.$ humidity) with standard diet and water in Pudong New Area Gongli Hospital. For the survival study, 62 mice were randomly separated into 4 groups: (1) sham $(n=8)$, (2) cecal ligation and double puncture (CLP) $(n=18),(3)$ CLP + cangrelor ( $5 \mathrm{mg} /$ $\mathrm{kg})(n=18)$, and (4) CLP + cangrelor $(20 \mathrm{mg} / \mathrm{kg})(n=18)$. Another 32 mice were randomly separated into 4 groups:
(1) sham $(n=8),(2)$ cecal ligation and double puncture (CLP) $(n=8)$, (3) CLP + cangrelor $(5 \mathrm{mg} / \mathrm{kg})(n=8)$, and (4) CLP + cangrelor $(20 \mathrm{mg} / \mathrm{kg})(n=8)$. The CLP was performed on isoflurane-anesthetized mice as previously described [21, 22]. Sham control animals underwent a laparotomy without ligation or double puncture. Mice were orally administrated with cangrelor $(5$ or $20 \mathrm{mg} /$ $\mathrm{kg}) 2 \mathrm{~h}$ before surgery. After surgery but prior to emergence, mice were fluid-resuscitated $(1 \mathrm{~mL} /$ mouse of sterile saline, subcutaneously). For the mechanism study, 32 mice were randomly separated into four groups: (1) sham $(n=8)$, (2) cecal ligation and double puncture (CLP) $(n=8)$, (3) CLP + cangrelor $(5 \mathrm{mg} / \mathrm{kg})(n=8)$, and (4) $\mathrm{CLP}+$ cangrelor $(20 \mathrm{mg} / \mathrm{kg})(n=8)$. Mice were killed $24 \mathrm{~h}$ after induction of CLP, plasma and lung were saved.

\section{Masson staining of the lung}

Paraffin sections of lung tissues were analyzed after several methods containing dewaxing rehydration, Ponceau S Fuchs in acid solution staining for $300 \mathrm{~s}$, by washing in $1 \%$ phosphomolybdic acid differentiation solution for $5 \mathrm{~min}$, aniline blue solution counterstaining for $300 \mathrm{~s}$, with $1 \%$ glacial acetic acid for $1 \mathrm{~min}$, alcohol gradient dehydration, transparency production using dimethylbenzene and xylene, and mounting.

\section{Flow cytometry}

For detection of surface CD40L expression on platelets, plasma was placed for $10 \mathrm{~min}$ at $36.5{ }^{\circ} \mathrm{C}$ that blocked FcyIII/II receptors to decrease nonspecific labeling, next incubated with fluorescein isothiocyanate-conjugated anti-CD41. Immobilization of cells with $1 \%$ formaldehyde; erythrocytes were lysed with fluorescence-activated cell sorting lysing solution (BD Biosciences, Shanghai, China), and neutrophils and platelets were then recovered by centrifugation at $300 \times g$ for $10 \mathrm{~min}$. Platelet activation was analyzed using PE-conjugated JON/A antibody (Emfret Analytics, Würzburg, Germany), which bound to the high affinity conformation of mouse $\alpha f f i n i$.

\section{RNA isolation and quantitative real-time PCR (qRT-PCR)} mRNA was obtained using TRIzol, respectively. cDNA was synthesized using M-MLV reverse transcriptase and Sangon reverse transcription primers. Relative transcript abundance was determined by the $2^{-\Delta \Delta C t}$ method and mRNA expression was normalized against $\beta$-actin. All amplification analyses were completed on QuantStudio ${ }^{\mathrm{TM}}$ 6 Flex Real-Time PCR System.

\section{Protein extraction and western blot analysis}

Lung tissues were lysed by RIPA buffer and protein concentrations were assessed by the BCA protein assay. About $20 \mu \mathrm{g}$ of protein from each example was divided 
by a $10 \%$ SDS-polyacrylamide gel and transferred to polyvinylidene fluoride membranes. Membranes were blocked with $10 \%$ skim milk in Tris-Buffered Saline with Tween-20 (TBST) and incubated with primary antibodies overnight at $4{ }^{\circ} \mathrm{C}$. Membranes were incubated with the corresponding secondary antibody for $1 \mathrm{~h}$ at room temperature and washed in TBST. Protein signals were detected using the Super ECL Plus Detection Reagent.

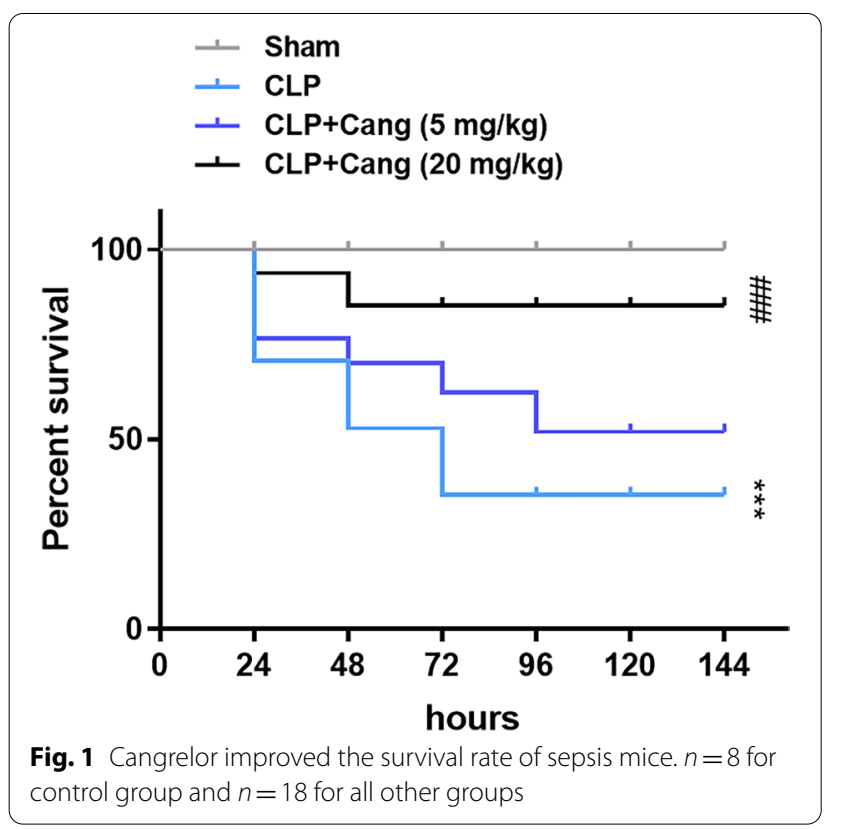

\section{Enzyme-linked immunosorbent assay (ELISA)}

Concentrations of the inflammatory cytokines in mice serum were measured with an ELISA kit following to manufacture protocols.

\section{Statistical analysis}

The effects of Cangrelor on the survival of mice were analyzed using the Kaplan-Meier curve and log-rank test. All other results were analyzed using one-way ANOVA analysis by SPSS statistical software for Windows, version 22.0 (SPSS, Chicago, IL, USA). The measurement data are expressed as the mean $\pm \mathrm{SD}$. A value of $p<0.05$ was deemed statistically significant.

\section{Results}

Cangrelor alleviates CLP-induced pulmonary injury

First, as shown in Fig. 1, the survival rate was $72.22 \%$ on the first $24 \mathrm{~h}$, decreased to $55.56 \%$ on the next $24 \mathrm{~h}$, and decreased a stable level of $38.89 \%$ on $72 \mathrm{~h}$ after CLP $(p<0.001)$. Treating with $5 \mathrm{mg} / \mathrm{kg}$ cangrelor did not enhance the survival rate compared with CLP group, while treating with $20 \mathrm{mg} / \mathrm{kg}$ cangrelor significantly improved the survival rate compared with CLP group $(p<0.001)$. Next, HE staining showed noticeable histopathologic changes including congestion, inflammatory cell infiltration, necrosis and degeneration while treating with $20 \mathrm{mg} / \mathrm{kg}$ cangrelor significantly ameliorate the histopathologic changes induced by CLP (Fig. 2A). In addition, we assessed the levels of apoptosis in mice lung tissues, using a TUNEL assay. The results showed that in the CLP group, lung tissues had a higher level of

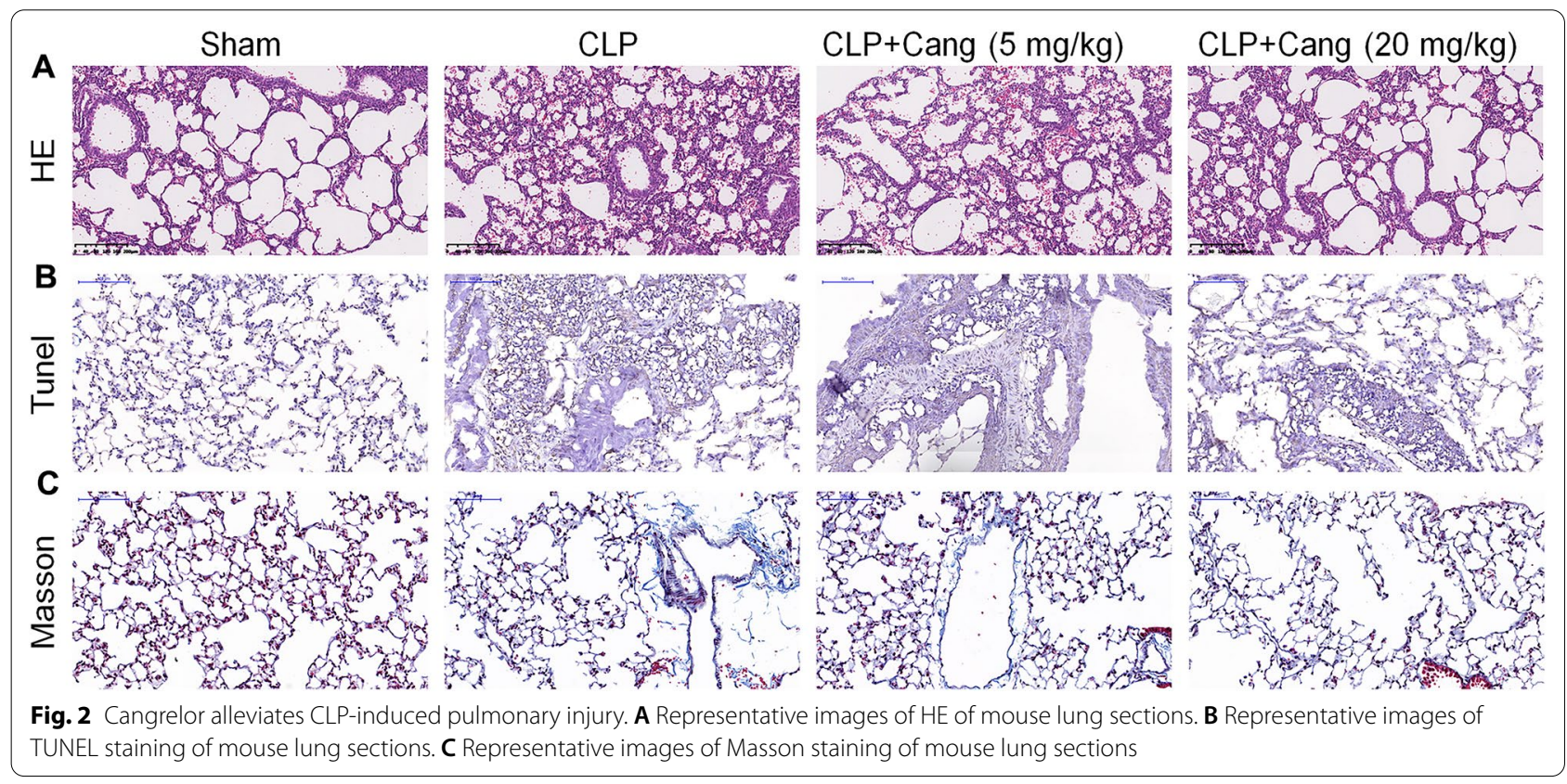


apoptotic cells, but cangrelor $(20 \mathrm{mg} / \mathrm{kg})$ reversed this result (Fig. 2B). Next, we assessed the anti-inflammatory effect of cangrelor. Masson staining showed that CLP mice had fibrotic changes, while there was significantly less damage in the CLP + cangrelor $(20 \mathrm{mg} / \mathrm{kg})$ group, as showed by blue staining (Fig. 2C).

\section{Cangrelor regulates platelet aggregation and neutrophil recruitment.}

The platelets surface level of CD40L was measured (Fig. 3A). The mean fluorescence intensity (MFI) was 72 in the sham group and 41 in the CLP group $(p<0.01)$. After the administration of cangrelor, the MFI was 46 when treated with $5 \mathrm{mg} / \mathrm{kg}$ cangrelor and 91 when treated with $20 \mathrm{mg} / \mathrm{kg}$ cangrelor which was significantly increased compared with CLP group $(p<0.001)$. Western blotting also presented that the level of platelet CD40L was meaningfully decreased in the CLP group in contrast to the sham group, while cangrelor $(20 \mathrm{mg} /$ $\mathrm{kg}$ ) increased this reduction (Fig. 3B). A cell assay of the broncho-alveolar lavage fluid (BALF) indicated the neutrophils in the broncho-alveolar was $0.26 \times 10^{6}$ in the sham mice while it was $1.76 \times 10^{6}$ when induced by CLP. After cangrelor treatment, the number of neutrophils decreased to $0.87 \times 10^{6}(p<0.001)$ (Fig. 3C). In addition, the pulmonary wet/dry ratio in the CLP group increased, which indicated the formation of pulmonary edema $(p<0.001)$. However, treatment with $20 \mathrm{mg} / \mathrm{kg}$ cangrelor significantly reversed this edema compared with CLP group $(p<0.01)$ (Fig. 3D).
A

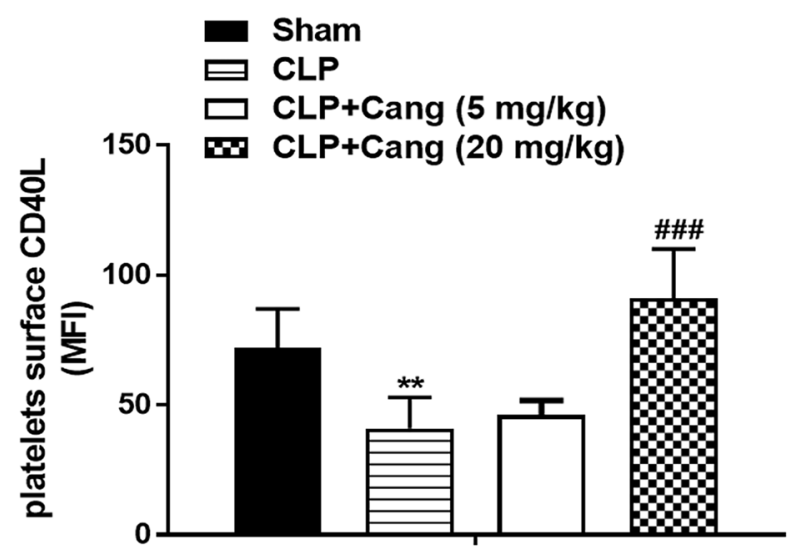

C

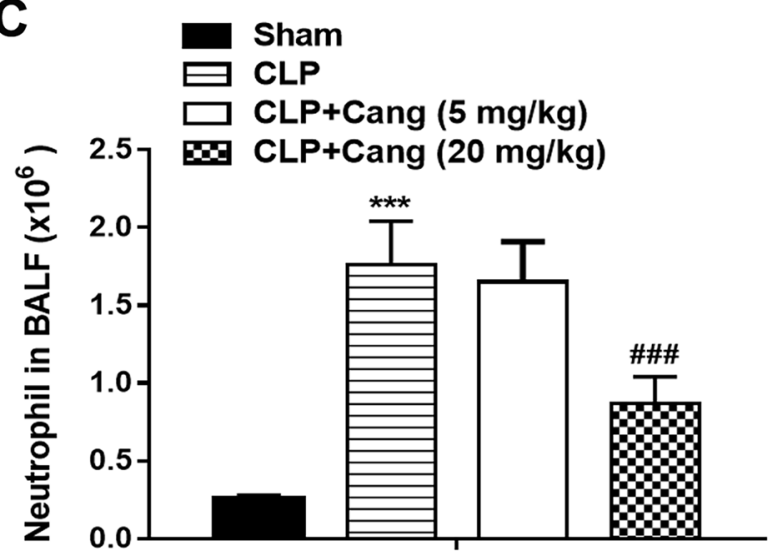

B
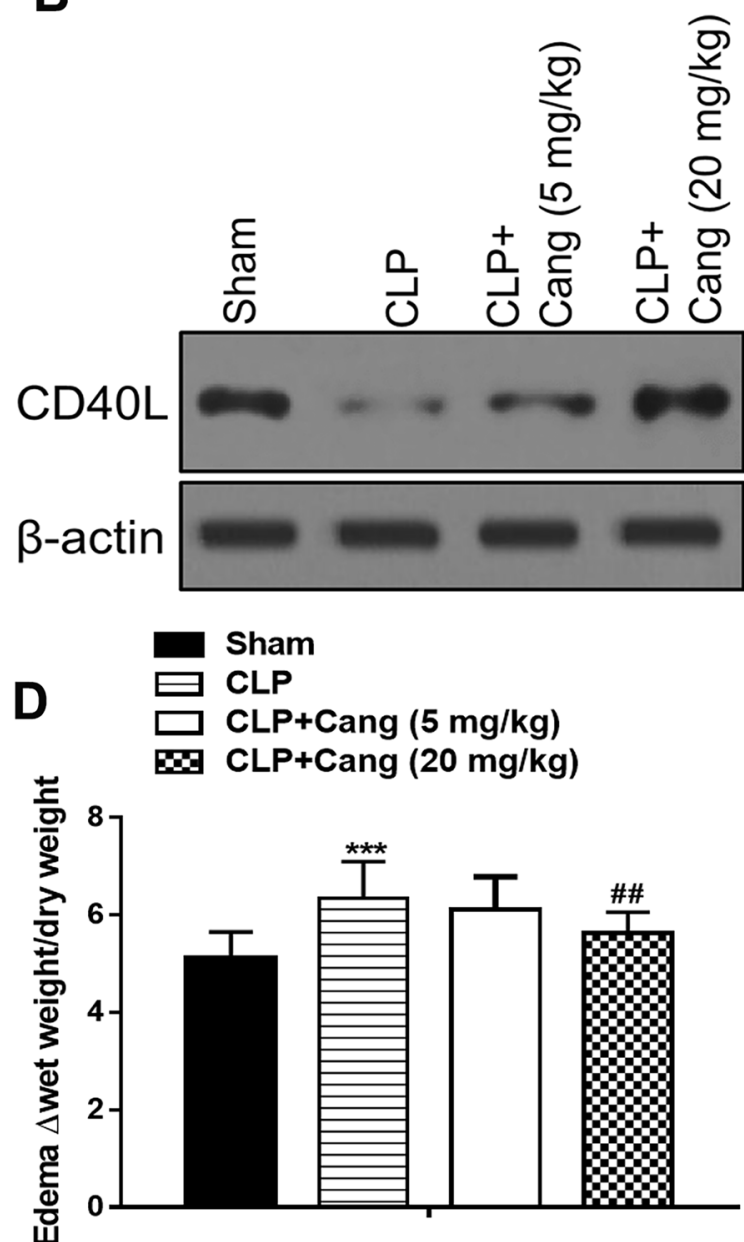

Fig. 3 Cangrelor regulates platelet aggregation and neutrophil recruitment. A Platelet surface expression CD40L. B Western blots of platelet lysates CD40L. C The number of neutrophils in BALF. D The levels of edema formation in the lung. Results are presented as means \pm SD $(n=8)$. ${ }^{* *} p<0.01,{ }^{* * *}$ $p<0.001$ compared to the sham control; ${ }^{\# \#} P<0.01,{ }^{\# \#} P<0.001$ compared to CLP 


\section{Cangrelor ameliorates the inflammatory response through GPR17}

CLP-induced levels of MPO in mice lung tissues were significantly increased $(p<0.01)$, whereas they decreased significantly in the presence of cangrelor $(p<0.01)$ (Fig. 4A). Using an ELISA, the concentrations of TNF- $\alpha$, IL- $1 \beta$, and IL- 6 in mice serum were meaningfully raised in the presence of CLP (all $p<0.001$ ), however, these levels were reduced by cangrelor $(20 \mathrm{mg} / \mathrm{kg}$ ) (IL- $1 \beta$ : $p<0.01$, TNF- $\alpha: p<0.05$, IL-6: $p<0.001$ ) (Fig. 4B). Former research has reported that cangrelor is the antagonist of GPR17 [23]. As shown in Fig. 4C, D western blotting and RT-PCR results indicated CLP upregulated GPR17 level in lung tissues $(p<0.001)$, whereas the administration of cangrelor $(20 \mathrm{mg} / \mathrm{kg})$ decreased its expression $(p<0.001)$.

\section{Discussion}

In our research, we demonstrated that cangrelor alleviated CLP-induced lung injury in abdominal sepsis by regulating platelet aggregation and the inflammatory response.

Previous studies reported that P2Y12 receptor antagonists such as clopidogrel and ticagrelor alleviate sepsis and lung damage through anti-platelet aggregation [13-15]. In addition, increasing evidence has shown that P2Y12 receptor antagonists decrease the inflammatory response in cardiovascular events, thrombosis, and atherosclerosis $[18,24]$, which indicates that P2Y12 regulation can affect inflammation through mechanisms that have not yet been fully clarified. Cangrelor is a secondgeneration P2Y12 antagonist and past studies have found

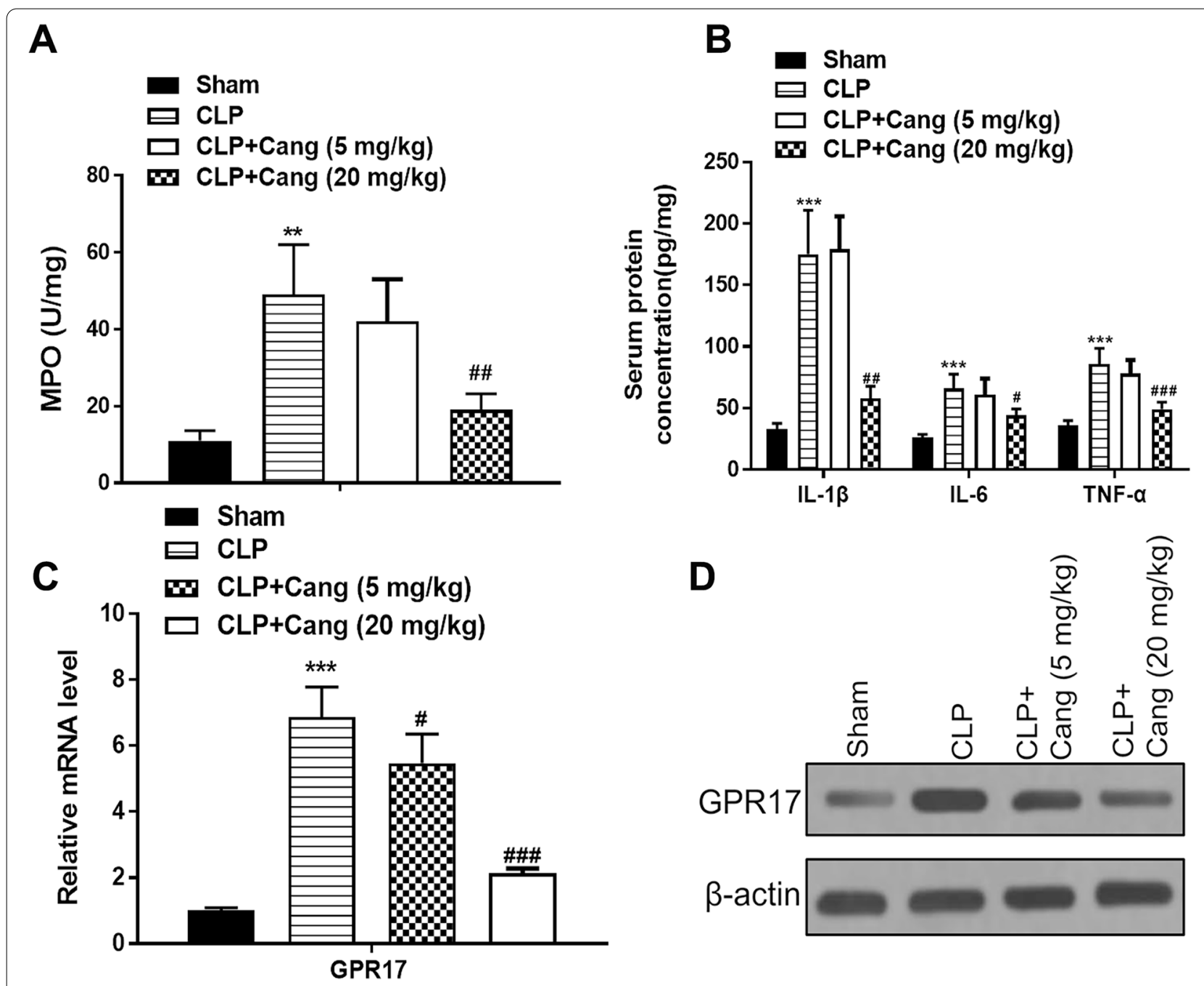

Fig. 4 Cangrelor ameliorates the inflammatory response through GPR17. A MPO concentration in lung tissue. B Serum concentrations of TNF-a, $\mathrm{IL}-1 \beta$, and IL-6 (C) mRNA level of GPR17. D Western blot of GPR17 in lung tissue. Results are presented as means $\pm \operatorname{SD}(n=8) .{ }^{* *} p<0.01,{ }^{* * * *} p<0.001$ compared to the sham control; \#\# $p<0.01, \# \# p<0.001$ compared to CLP 
that cangrelor alleviates the inflammatory response in lung fibrosis [25], chronic inflammatory pain [26], and neuropathic pain [27]. In the present study, we found that pre-treatment of cangrelor decreased CLP-induced pulmonary injury by modulating the inflammatory response and significantly increased survival in sepsis mice. However, the diagnosis and treatment of sepsis usually occur after the onset of the disease. Hence, we will further investigate the time responses of cangrelor and evaluated the therapeutic effect of cangrelor at different time after CLP. Besides, lipopolysaccharide (LPS)-stimulated lung epithelial/endothelial cells are commonly used to mimic in vitro sepsis-induced lung injury model $[28,29]$. What is more, Amison et al. [30] found that pulmonary neutrophil recruitment induced by intranasal LPS administration was inhibited in mice administered either with P2Y receptor antagonists. Hence, further studies are required to establish the effectiveness of treatment with the P2Y12 receptor antagonists, cangrelor in LPS-induced in vitro model.

Previous studies have also reported the release of soluble CD40L from platelets in sepsis-regulated platelet-dependent neutrophil lung accumulation [31, 32]. However, the mechanism for modulating CD40L platelet shedding in sepsis is not clear. In our study, CLP induced a decrease of surface CD40L, which was significantly increased after treatment with cangrelor. In addition, the increase of neutrophils in BALF was attenuated by cangrelor treatment. The increased of lymphocytes, macrophages and eosinophils in BALF also indicates lung damage. The immune regulation of macrophages is also considered to be an important target for sepsis [33]. Further research should be undertaken to investigate the effect of cangrelor on macrophage-specific therapeutic targeting their immunometabolism during sepsis and regulation of macrophage.

Cangrelor has been confirmed to effectively inhibit the expression of GPR17 [23, 34, 35]. There is increasing evidence that the modulation of GPR17 could ameliorate inflammatory responses and injury, which suggested that GPR17 plays an important role in injury reparation [36]. For example, inhibiting GPR17 repressed the activation of microglia and alleviated inflammation induced by ischemic in rats [34, 37]. Inhibition of GPR17 also protects against myocardial fibrosis caused by cardiac ischemia [38], and we further confirmed that the administration of cangrelor reversed the rise of GPR17 induced by CLP, as well as ameliorating the inflammatory response. However, the relationship between P2Y12 receptor and GPR17 is still unknown. Besides, whether cangrelor interacts with GPR17 directly or through other unknown pathways remains unclear. In future research, we will investigate drug binding site of cangrelor on GPR17 via molecular docking or surface plasmon resonance analysis.

\section{Conclusion}

Our study suggested that cangrelor inhibited the expression of GPR17 in lung tissue, thus attuned the inflammatory response and the recruitment of neutrophils in BALF, and ameliorated CLP-mediated pulmonary injury during sepsis. In summary, our findings revealed that cangrelor could ameliorate lung injury and increased survival rate of mice with CLP-induced sepsis. These results suggest that cangrelor could be a potential target treatment for sepsis-induced lung injury.

\section{Abbreviations}

BALF: Bronchoalveolar lavage fluid; CLP: Cecal ligation and puncture; GPR17: G-protein-coupled receptor 17; MPO: Myeloperoxidase; MFI: Mean fluorescence intensity; TUNEL: TdT-mediated dUTP nick-end labeling; HE: Staining hematoxylin-eosin staining; BCA: Butyleyanoacrylate; RIPA: Radio immunoprecipitation assay; qRT-PCR: Quantitative reverse transcription polymerase chain reaction; TBST: Tris-buffered saline with tween-20; ELISA: Enzyme-linked immunosorbent assay; LPS: Lipopolysaccharide.

\section{Acknowledgements}

Not applicable.

\section{Authors' contributions}

QK, QJ and DG designed study, edited and corrected the manuscript. QL and $\mathrm{RL}$ performed the experiments and drafted the article. GL, MH, GC and LX assisted perform the study and analyzed data. All the authors read and approved the final manuscript.

\section{Funding}

The present study was funded by Shanghai Pudong New Area Health System Excellent Youth Medical Personnel Training Program (No. PWRq2017-09), Shanghai Pudong New Area Health System Key Specialty construction Project (No. PWZzk2017-05) and Shanghai Municipal Health and Family Planning Commission Research Project (No. 201640405).

Availability of data and materials

The data that support the findings of this study are available from the corresponding author upon reasonable request.

\section{Declarations}

Ethics approval and consent to participate

This study was approved by the Experimental Animal Ethical Committee of Pudong New Area Gongli Hospital.

\section{Consent for publication}

Written informed consent for publication was collected from each participant.

\section{Competing interests}

All the authors declare they have no competing interests.

\section{Author details}

${ }^{1}$ Department of Critical Care Medicine, Shanghai Gongli Hospital, The Second Military Medical University, Shanghai 200135, People's Republic of China.

${ }^{2}$ Department of Endocrinology, Shanghai Gongli Hospital, The Second Military Medical University, Shanghai 200135, People's Republic of China. ${ }^{3}$ Postgraduate Training Base in Shanghai Gongli Hospital, Ningxia Medical University, Shanghai 200135, People's Republic of China. 
Received: 21 May 2020 Accepted: 21 June 2021

Published online: 06 July 2021

\section{References}

1. Rudd KE, Johnson SC, Agesa KM, Shackelford KA, Tsoi D, Kievlan DR, Colombara DV, Ikuta KS, Kissoon N, Finfer S, et al. Global, regional, and national sepsis incidence and mortality, 1990-2017: analysis for the global burden of disease study. Lancet. 2020;395:200-11.

2. Shankar-Hari M, Phillips GS, Levy ML, Seymour CW, Liu VX, Deutschman CS, Angus DC, Rubenfeld GD, Singer M, Sepsis Definitions Task F. Developing a new definition and assessing new clinical criteria for septic shock: for the third international consensus definitions for sepsis and septic shock (sepsis-3). JAMA. 2016;315:775-87.

3. Zhou H, Deng M, Liu Y, Yang C, Hoffman R, Zhou J, Loughran PA, Scott MJ, Neal MD, Billiar TR. Platelet HMGB1 is required for efficient bacterial clearance in intra-abdominal bacterial sepsis in mice. Blood Adv. 2018;2:638-48.

4. Cinel I, Opal SM. Molecular biology of inflammation and sepsis: a primer. Crit Care Med. 2009;37:291-304.

5. Dickson RP, Singer BH, Newstead MW, Falkowski NR, Erb-Downward JR, Standiford TJ, Huffnagle GB. Enrichment of the lung microbiome with gut bacteria in sepsis and the acute respiratory distress syndrome. Nat Microbiol. 2016;1:16113.

6. National Heart L, Blood Institute ACTN, Truwit JD, Bernard GR, Steingrub J, Matthay MA, Liu KD, Albertson TE, Brower RG, Shanholtz C, et al. Rosuvastatin for sepsis-associated acute respiratory distress syndrome. N Engl J Med. 2014:370:2191-200.

7. Force ADT, Ranieri VM, Rubenfeld GD, Thompson BT, Ferguson ND, Caldwell E, Fan E, Camporota L, Slutsky AS. Acute respiratory distress syndrome: the Berlin definition. JAMA. 2012;307:2526-33.

8. Matthay MA, Zemans RL, Zimmerman GA, Arabi YM, Beitler JR, Mercat A, Herridge M, Randolph AG, Calfee CS. Acute respiratory distress syndrome. Nat Rev Dis Primers. 2019;5:18.

9. Zhou J, Qian C, Zhao M, Yu X, Kang Y, Ma X, Ai Y, Xu Y, Liu D, An Y, et al. Epidemiology and outcome of severe sepsis and septic shock in intensive care units in mainland China. PLoS ONE. 2014;9: e107181.

10. Cerletti C, Tamburrelli C, Izzi B, Gianfagna F, de Gaetano G. Platelet-leukocyte interactions in thrombosis. Thromb Res. 2012;129:263-6.

11. Losche W, Boettel J, Kabisch B, Winning J, Claus RA, Bauer M. Do aspirin and other antiplatelet drugs reduce the mortality in critically ill patients? Thrombosis. 2012;2012:720254.

12. Winning J, Reichel J, Eisenhut $Y$, Hamacher J, Kohl M, Deigner HP, Claus RA, Bauer M, Losche W. Anti-platelet drugs and outcome in severe infection: clinical impact and underlying mechanisms. Platelets. 2009;20:50-7.

13. Rahman M, Gustafsson D, Wang Y, Thorlacius H, Braun OO. Ticagrelor reduces neutrophil recruitment and lung damage in abdominal sepsis. Platelets. 2014;25:257-63

14. Liverani E, Rico MC, Tsygankov AY, Kilpatrick LE, Kunapuli SP. P2Y12 receptor modulates sepsis-induced inflammation. Arterioscler Thromb Vasc Biol. 2016;36:961-71.

15. Seidel M, Winning J, Claus RA, Bauer M, Losche W. Beneficial effect of clopidogrel in a mouse model of polymicrobial sepsis. J Thromb Haemost. 2009;7:1030-2.

16. Gachet C. ADP receptors of platelets and their inhibition. Thromb Haemost. 2001:86:222-32

17. Kunapuli SP, Dorsam RT, Kim S, Quinton TM. Platelet purinergic receptors. Curr Opin Pharmacol. 2003;3:175-80.

18. Nylander $\mathrm{S}$, Schulz R. Effects of $\mathrm{P} 2 \mathrm{Y} 12$ receptor antagonists beyond platelet inhibition-comparison of ticagrelor with thienopyridines. $\mathrm{Br}$ J Pharmacol. 2016:173:1163-78.

19. Wu L, Zhao F, Dai M, Li H, Chen C, Nie J, Wang P, Wang DW. P2y12 receptor promotes pressure overload-induced cardiac remodeling via plateletdriven inflammation in mice. Hypertension. 2017;70:759-69.

20. Mansour A, Bachelot-Loza C, Nesseler N, Gaussem P, Gouin-Thibault I. P2Y12 inhibition beyond thrombosis: effects on inflammation. Int J Mol Sci. 2020:21:1391.
21. Kahner BN, Shankar H, Murugappan S, Prasad GL, Kunapuli SP. Nucleotide receptor signaling in platelets. J Thromb Haemost. 2006;4:2317-26.

22. Quinton TM, Murugappan S, Kim S, Jin J, Kunapuli SP. Different G proteincoupled signaling pathways are involved in alpha granule release from human platelets. J Thromb Haemost. 2004;2:978-84.

23. Marucci G, Dal Ben D, Lambertucci C, Santinelli C, Spinaci A, Thomas A, Volpini R, Buccioni M. The G protein-coupled receptor GPR17: overview and update. Chem Med Chem. 2016;11:2567-74.

24. Liverani E, Kilpatrick LE, Tsygankov AY, Kunapuli SP. The role of P2Y (1)(2) receptor and activated platelets during inflammation. Curr Drug Targ. 2014;15:720-8

25. Zhan TW, Tian YX, Wang Q, Wu ZX, Zhang WP, Lu YB, Wu M. Cangrelor alleviates pulmonary fibrosis by inhibiting GPR17-mediated inflammation in mice. Int Immunopharmacol. 2018;62:261-9.

26. Beko K, Kovanyi B, Goloncser F, Horvath G, Denes A, Kornyei Z, Botz B, Helyes Z, Muller CE, Sperlagh B. Contribution of platelet P2Y12 receptors to chronic complete Freund's adjuvant-induced inflammatory pain. J Thromb Haemost. 2017;15:1223-35.

27. Horvath G, Goloncser F, Csolle C, Kiraly K, Ando RD, Baranyi M, Kovanyi B, Mate Z, Hoffmann K, Algaier I, et al. Central P2Y12 receptor blockade alleviates inflammatory and neuropathic pain and cytokine production in rodents. Neurobiol Dis. 2014;70:162-78.

28. Xia W, Zhang H, Pan Z, Li G, Zhou Q, Hu D, Liu Y. Inhibition of MRP4 alleviates sepsis-induced acute lung injury in rats. Int Immunopharmacol. 2019;72:211-7.

29. Chen Q, Liu J, Wang W, Liu S, Yang X, Chen M, Cheng L, Lu J, Guo T, Huang F. Sini decoction ameliorates sepsis-induced acute lung injury via regulating ACE2-Ang (1-7)-mas axis and inhibiting the MAPK signaling pathway. Biomed Pharmacother. 2019;115:108971.

30. Amison RT, Arnold S, O'Shaughnessy BG, Cleary SJ, Ofoedu J, Idzko M, Page CP, Pitchford SC. Lipopolysaccharide (LPS) induced pulmonary neutrophil recruitment and platelet activation is mediated via the P2Y1 and P2Y14 receptors in mice. Pulm Pharmacol Ther. 2017:45:62-8.

31. Rahman M, Zhang S, Chew M, Ersson A, Jeppsson B, Thorlacius H. Platelet-derived CD40L (CD154) mediates neutrophil upregulation of Mac-1 and recruitment in septic lung injury. Ann Surg. 2009;250:783-90.

32. Rahman M, Zhang S, Chew M, Syk I, Jeppsson B, Thorlacius H. Platelet shedding of CD40L is regulated by matrix metalloproteinase-9 in abdominal sepsis. J Thromb Haemost. 2013;11:1385-98.

33. Kumar $\mathrm{V}$. Targeting macrophage immunometabolism: Dawn in the darkness of sepsis. Int Immunopharmacol. 2018;58:173-85.

34. Ciana P, Fumagalli M, Trincavelli ML, Verderio C, Rosa P, Lecca D, Ferrario S, Parravicini C, Capra V, Gelosa P, et al. The orphan receptor GPR17 identified as a new dual uracil nucleotides/cysteinyl-leukotrienes receptor. EMBO J. 2006;25:4615-27.

35. Lecca D, Trincavelli ML, Gelosa P, Sironi L, Ciana P, Fumagalli M, Villa G, Verderio C, Grumelli C, Guerrini U, et al. The recently identified P2Y-like receptor GPR17 is a sensor of brain damage and a new target for brain repair. PLOS ONE. 2008;3:e3579.

36. Matsui H, Sopko NA, Hannan JL, Reinhardt AA, Kates M, Yoshida T, Liu X, Castiglione F, Hedlund P, Weyne E, et al. M1 macrophages are predominantly recruited to the major pelvic ganglion of the rat following cavernous nerve injury. J Sex Med. 2017;14:187-95.

37. Zhao $B$, Zhao $C Z$, Zhang $X Y$, Huang $X Q$, Shi WZ, Fang $S H$, Lu YB, Zhang WP, Xia Q, Wei EQ. The new P2Y-like receptor G protein-coupled receptor 17 mediates acute neuronal injury and late microgliosis after focal cerebral ischemia in rats. Neuroscience. 2012:202:42-57.

38. Cosentino S, Castiglioni L, Colazzo F, Nobili E, Tremoli E, Rosa P, Abbracchio MP, Sironi L, Pesce M. Expression of dual nucleotides/cysteinyl-leukotrienes receptor GPR17 in early trafficking of cardiac stromal cells after myocardial infarction. J Cell Mol Med. 2014;18:1785-96.

\section{Publisher's Note}

Springer Nature remains neutral with regard to jurisdictional claims in published maps and institutional affiliations. 